\title{
$\beta$-DIKETO STRUCTURE FOR QUANTUM INFORMATION PROCESSING
}

\author{
Ž. Rinkevičius ${ }^{\mathrm{a}}$, A. Tamulis ${ }^{\mathrm{b}}$, and J. Tamulienè ${ }^{\mathrm{b}}$ \\ ${ }^{a}$ Theoretical Chemistry, Royal Institute of Technology, SCFAB, Roslagstullsbacken 15, SE-10691 Stockholm, Sweden \\ ${ }^{\mathrm{b}}$ Institute of Theoretical Physics and Astronomy of Vilnius University, A. Goštauto 12, LT-01108 Vilnius, Lithuania \\ E-mail: gicevic@itpa.lt
}

Received 18 July 2006

\begin{abstract}
Hypothetical qubit system designed for quantum information processing based on spatially ordered organic radicals $(S=$ $1 / 2$ ) in self-assembled monolayer is described and application of quantum chemistry methods in search of suitable radicals is outlined. Exemplifying calculation of relevant magnetic properties of diketo type neutral radicals is presented and suitability of these compounds for building blocks of quantum computing device based on self-assembled monolayer of radicals is assessed.
\end{abstract}

Keywords: qubits, quantum computing device, neutral radical, $g$-tensor

PACS: $31.15 . \mathrm{Ar}$

\section{Introduction}

It was recently suggested that self-assembling monolayer (SAM) systems could be used to create a macroscopic ensemble of quantum entangled spin groups, as a first step toward parallel quantum information processing [1]. The unpaired electron spin of each radical (radicals are in doublet ground states $S=1 / 2$ ) acts as qubit in spin group and a gradient of static external magnetic field is applied to a spatially ordered SAM of radicals in order to separate the energy levels of qubits via Zeeman effect. The nonlinear interaction between qubits, required for achieving entanglement in spin group, in such a system is provided by classical dipole-dipole interaction between spins of radicals or alternatively by exchange interaction. In this choice there are involved several criteria for the chemical structure of these molecules: (i) an unpaired electronic spin representing an elementary qubit, (ii) a specific group to provide an attachment of the molecule to a substrate in SAM, (iii) a specific group or structural elements to provide self-organization characteristics, (iv) a large separation of an energy level of qubit via Zeeman effect to lower the decoherence, (v) an entanglement in spin group.

Modern quantum chemical methods provide powerful tools for theoretical modelling and analysis of molecular electronic structure and may be used to guide the synthetic effort $[2,3]$. In particular, the small carbon-centred $\beta$-radical molecules (8-14 atoms) possessing a $\beta$-diketo structure have been investigated in the scope of unrestricted Hartree-Fock (UHF) and unrestricted density functional theory (UDFT) methods [4]. In [4] the hyperfine interactions in small molecules are presented without addressing their suitability for quantum information processing and no claims are made towards using the system for quantum computation, while our aim is to demonstrate that a $\beta$-diketo structure could be used in quantum computation.

Here we report the results of quantum chemical investigations of an organic radical moiety. These simulations show that the suggested neutral radicals satisfy all the constraints listed above and may serve as prototypes for designing molecules to be used in experiments targeting quantum computation with SAM structures.

\section{Computational methodology}

The quantum chemical $a b$ initio density functional theory (DFT) investigations were applied with the Berny geometry optimization to gain chemical shift information on an isolated molecule $[4,5]$. Currently, the UB3LYP model is considered to be the most appropriate model to take into consideration electron correlations in large open-shell neutral radical molecules $[4,5]$. To obtain accurate optimal molecular geometries, we use the $6-311 \mathrm{G}^{* *}$ basis set which includes 
$(5 D, 7 F)$ polarized atomic orbitals (the standard tables [6] give the appropriate basis set description). To analyse the spatial electronic spin localization and stability at a relaxed molecule geometry, we subsequently use extended EPR-II basis set (also tabulated in Ref. [6]). The EPR-II basis set includes the reoptimized Huzinaga-Dunning double-zeta $[7,8]$ basis sets, augmented with additional polarization functions and uncontracted in outer core-inner valence region, and provides a good accuracy for modelling various molecular properties in organic radicals as shown by Barone [9]. To investigate the $-\left(\mathrm{CH}_{2}\right)_{n}-$ tail chain influence to the unpaired spin localization and hyperfine splitting, the investigation of the above molecule with 12 and 19 elements long tail chain was performed applying UB3LYP / EPR-II approach. Obtained results indicated no influence of the $-\left(\mathrm{CH}_{2}\right)_{n}-$ tail chain to the unpaired spin localization and hyperfine coupling. Additionally, in [10] it is exhibited that adding a $-\left(\mathrm{CH}_{2}\right)_{n}$ - tail chain does not influence significantly the radical electron $g$-factor. On the other hand, the largest isotropic Fermi contact couplings are at an atom in the region where non-compensated electron is present [11]. So, the $-\left(\mathrm{CH}_{2}\right)_{n}$ - tail chain cutting has not changed significantly the above-mentioned parameter. Thus, the $-\left(\mathrm{CH}_{2}\right)_{n}$ - tail chain is shorter, with only three elements, and the additional investigations have been performed using the restricted Kohn-Sham formalism for first order properties applying restrictedunrestricted (R-U) approach.

The full geometry optimization in the ground state of the shorter molecule was performed using DFT in the framework of Becke's three parameter hybrid method and LYP gradient-corrected correlation functional (B3LYP) model in the 6-311G** basis sets using Gaussian 03 software package $[6,7]$. Then, the radical electron $g$-factor is investigated applying the approach presented in [12]. Results of the isotropic hyperfine coupling constant using the R-U approach at the DFT level are also presented. In these cases the BP86 functional with Huz-II basis with uncontracted $s$-functions and additional two tight $s$-function set is applied.

\section{Analysis of electronic structure in neutral radical molecules}

A view of a short neutral radical molecule with a $\beta$-diketone structure is present in Fig. 1.

Firstly, it is necessary to mention that the $-\mathrm{COOH}$ group in the lower terminus of this molecule can provide the necessary attachment to the substrate for cases
Table 1. The obtained isotropic hyperfine coupling. The values are obtained by approach presented in [12].

\begin{tabular}{cc}
\hline Atoms & Isotropic hyperfine coupling, $\mathrm{MHz}$ \\
\hline $\mathrm{H} 14$ & 6.82 \\
$\mathrm{H} 15$ & -6.57 \\
$\mathrm{H} 16$ & -6.57 \\
$\mathrm{H} 17$ & -7.83 \\
$\mathrm{H} 18$ & -2.56 \\
$\mathrm{H} 19$ & -2.56 \\
$\mathrm{H} 20$ & 0.16 \\
$\mathrm{H} 21$ & 0.16 \\
$\mathrm{H} 22$ & 0.00 \\
$\mathrm{H} 23$ & 0.43 \\
$\mathrm{H} 24$ & 0.43 \\
$\mathrm{H} 25$ & -0.05 \\
H26 & -0.05 \\
\hline
\end{tabular}

of a variety of inorganic oxide materials such as aluminum oxide (see $[13,14]$ ). This implies that a specific group to provide an attachment of the molecule to a substrate SAM is present, i. e. one of the criteria to choose the structure for experimental implementation are satisfied. The radicals contain hydrophobic tail that can be used for self-assembled monolayer formation [15]. The unpaired, spatially localized spin of 0.44 and 0.50 electron on $\mathrm{O} 10$ and $\mathrm{O} 11$ atoms that could represent an elementary qubit is also present. The conclusion follows from analysis of spin density distribution. It is not exhibited that a self-organization of this $\beta$-diketo structure is possible, but without any doubt the criteria to choose the molecule for experimental implementation are satisfied. It is well known that the hyperfine structure of molecular spectra is an illuminating tool for probing electronic structure. For radicals, this hyperfine structure is typically dominated by magnetic interactions between nuclei with nonzero spin and the spin or orbital angular momentum of the unpaired electrons [16]. Thus, the hyperfine coupling of the hydrogen atoms has been evaluated (Table 1) to confirm that the unpaired, spatially localised electronic spin representing an elementary qubit is present at the $\mathrm{O} 11$ and $\mathrm{O} 12$ atoms.

The data indicate very weak coupling for $\mathrm{H} 22, \mathrm{H} 25$, $\mathrm{H} 26$ that are very far from the region where the unpaired electron is localised. The large values of the istropic hyperfine coupling of the $\mathrm{H} 17$ atom and $\mathrm{H} 14$, $\mathrm{H} 15, \mathrm{H} 16$ indicate strong interactions between spins of these atoms and spins of the unpaired electrons.

In order to obtain more results charaterizing the above molecule as a promising candidate for quantum computation, the electronic $g$-tensor, which accounts for the influence of the local electronic environment in the molecule on the unpaired electrons compared to 


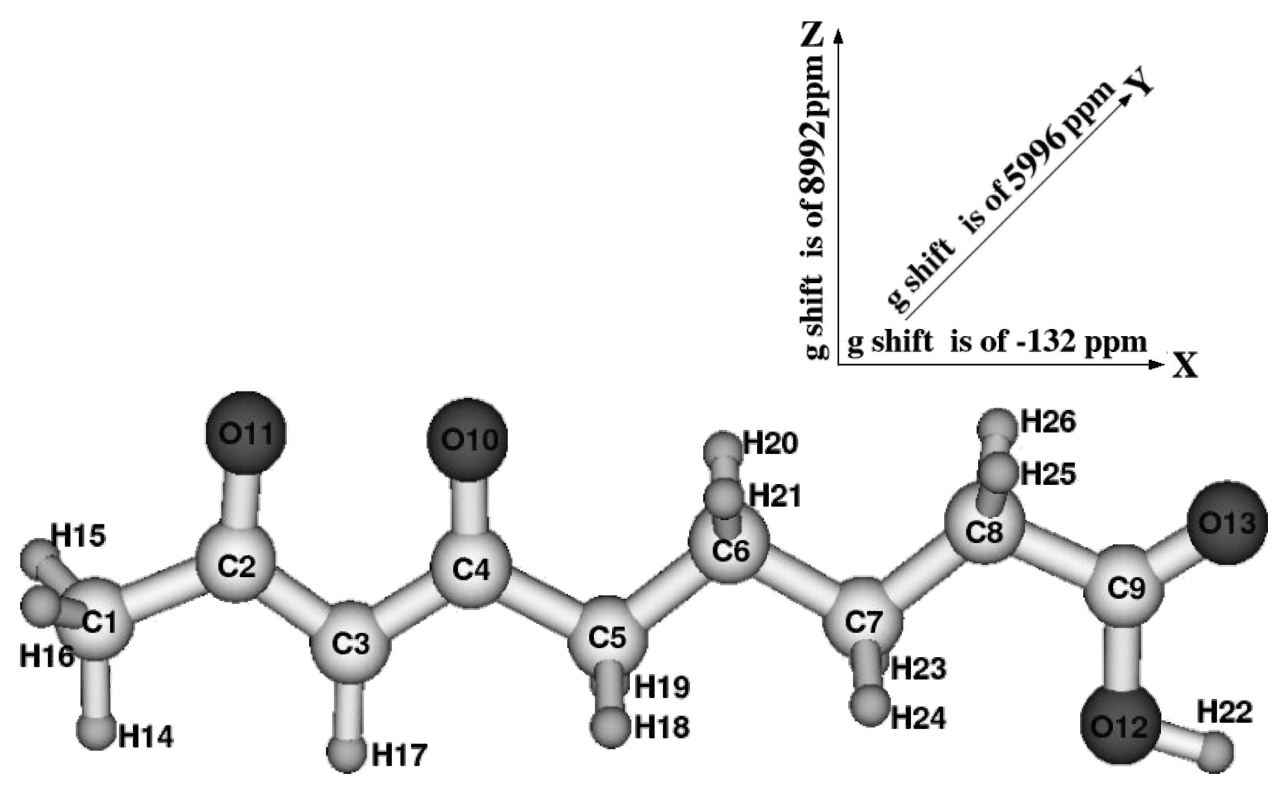

Fig. 1. Geometry of optimised neutral radical molecule with $\beta$-diketo structure. Placement of the molecule and $g$-tensor components on $x, y, z$ axes are indicated. The values of $g$-tensor components are also presented.

the free electron, will also be investigated. When both the molecule and the created field $g$-tensors are known, it is possible to choose the angle between the above $g$-tensors in such a way that the spin-dipole interaction is absent. Thus, the decoherence is lowered. The electronic $g$-tensor components of this molecule are equal to $-132 \mathrm{ppm}\left(g_{x x}\right), 5996 \mathrm{ppm}\left(g_{y y}\right), 8992 \mathrm{ppm}\left(g_{z z}\right)$. So, selected radical has high electronic $g$-tensor with large $g_{z z}$ and $g_{y y}$ components and only $g_{x x}$ is small. Thus the $g_{x x}$ tensor component is close to the free electron $g$-factor. Such orientation of the $g$-tensor components allows us to foresee that significant difficulties for the quantum computation prospects like the necessity to have well defined frequencies of the transitions should be absent in this case, because fixed orientation of the electronic $g$-tensor principal axes with respect to the external magnetic field will take place. Moreover, the $g_{y y}$ component of the $g$-tensor goes out of the molecule plane (Fig. 1). So the quantum computation with spin qubit could be performed without any difficulty.

\section{Conclusions}

Using quantum chemical methods based on the density functional theory we have studied the molecule with $\beta$-diketo structure. Our analysis of the spatial localization of the electron spin density and the bond orders shows that the neutral radicals satisfy the requirements formulated in our work. It implies that the specific group to provide an attachment of the molecule to a substrate SAM is present and a self-assembled monolayer formation should take place. The elementary qubit is represented by the unpaired electron spatially localized on $\mathrm{O} 10$ and $\mathrm{O} 11$ atoms. The isotropic hyperfine coupling analysis confirms the presence of unpaired electron spin on the above oxygen atoms.

The fixed orientation of the electronic $g$-tensor principal axes with respect to the external magnetic field supports the absence of significant difficulties for the quantum computation prospects. It is not exhibited that a self-organization of this $\beta$-diketo structure is possible, but without any doubt the above criteria to choose the molecule for experimental implementation are satisfied. Hence the $\beta$-diketo structure is a good candidate to be used in quantum computation.

\section{Acknowledgement}

This work was supported by the NorFa grant "Quantum Modelling of Molecular Materials".

\section{References}

[1] G.P. Berman, V.I. Tsifrinovich, and D.L. Alara, Phys. Rev. B 6619, 3406 (2002).

[2] D.B. Cook, Handbook of Computational Quantum Chemistry (Oxford University Press, New York, 1998).

[3] A. Szabo and N.S. Ostlund, Modern Quantum Chemistry: Introduction to Advanced Electronic Structure Theory (McGraw-Hill, New York, 1989). 
[4] Density-Functional Methods in Chemistry and Materials Science, Ed. M. Springborg (John Wiley \& Sons, 1997).

[5] F. Jensen, Introduction to Computational Chemistry (John Wiley \& Sons, 1999).

[6] Extensible Computational Chemistry Environment Basis Set Database, Environmental and Molecular Sciences Laboratory at Pacific Northwest Laboratory, P.O. Box 999, Richland, Washington 99352, USA.

[7] S. Huzinaga, J. Chem. Phys. 42, 1293 (1965).

[8] T.H. Dunning, Jr., J. Chem. Phys. 53, 2823 (1970).

[9] V. Barone, in: Recent Advances in Density Functional Methods, Part 1, Ed. D.P. Chong (World Scientific, Singapore, 1995).

[10] Z. Rinkevicius, L. Telyatnyk, O. Vahtras, and H. Agren, Time-depended density functional theory for hyperfine coupling constants with the restrictedunrestricted approach (accepted for publication in J. Chem. Phys.); Z. Rinkevicius, L. Telyatnyk, O. Vahtras, and H. Agren, J. Chem. Phys. 121, 7614
(2004).

[11] J. Tamuliene, A. Tamulis, and J. Kulys, Nonlinear Analysis: Modelling and Control 9, 185 (2004).

[12] Z. Rinkevicius, G.P. Berman, D.L. Allara, and V.I. Tsifrinovich, Characteristic parameters and dynamics of two-qubit system in self-assembled monolayers (under revision in Phys. Rev. B); B.C. Stipe, H.J. Mamin, C.S. Yannoni, T.D. Stowe, T.W. Kenny, and D. Rugar, Phys. Rev. Lett. 87, 277602 (2001); G.P. Berman, D.I. Kamenev, and V.I. Tsifrinovich, Phys. Rev. A 66, 023405 (2002).

[13] U. Ulman, Chem. Rev. 96, 1533 (1996).

[14] G. Fletcher, S. Mason, J. Terrett, and M. Soloviev, J. Nanobiotechnol. 1:1 (2003). www. jnanobiotechnology. com

[15] Yi Li, K.-S. Moon, and C.P. Wong, J. Electron. Mater. 34, 266 (2005).

[16] J.A.J. Fitzpatrick, F.R. Manby, and C.M. Western, J. Chem. Phys. 122, 084312-1 (2005).

\title{
$\beta$-DIKETONINIS DARINYS KVANTINĖS INFORMACIJOS APDOROJIMUI
}

\author{
Ž. Rinkevičius ${ }^{\mathrm{a}}$, A. Tamulis ${ }^{\mathrm{b}}$, J. Tamuliené ${ }^{\mathrm{b}}$ \\ ${ }^{a}$ Karališkasis technologijos institutas, Stokholmas, Švedija \\ ${ }^{\mathrm{b}}$ VU Teorinès fizikos ir astronomijos institutas, Vilnius, Lietuva
}

\section{Santrauka}

Pateikti $\beta$-diketoninès molekulès kvantinès chemijos tyrimai, atlikti tankio funkcionalo metodu, naudojant (UB3LYP) 6-311G** bazès artinị. Parodyta, kad nagrinèjama molekulè galètų būti panaudota elektronu paramagnetinio rezonanso (EPR) kvantiniuose kompiuteriuose su savisusirenkančiais neutraliu radikalų sluoksniais (Self-assembling monolayers, SAM), prijungtais prie padèklų.

Gauti ir straipsnyje pateikti rezultatai parodè, kad tos molekulès cheminè sandara patenkina šiuos kriterijus:

1) žinoma nesuporuoto elektrono, kuris gali būti panaudojamas kaip q bitas, lokalizacijos vieta;
2) molekulès sudètyje yra $-\mathrm{COOH}$ grupè, kuri reikalinga radikalui pritvirtinti prie padèklo;

3) galima radikalo sluoksnio saviorganizacija, nes nagrinejjamo radikalo sudètyje yra $-\left(\mathrm{CH}_{2}\right)_{n}$ - grupès;

4) nesuporuoto elektrono sukinio orientacija yra tokia, kad aplinkos įtaka yra mažiausia ir nebūtų sudètinga šiuo sukiniu operuoti.

Šie kriterijai yra pirminiai, atliekant radikalų atranką eksperimentiniams tyrimams. Tad, remiantis aukščiau minètais pastebejimais, padaryta išvada, kad $\beta$-diketoninè molekulè yra tinkama naudoti SAM technologijos EPR kvantiniuose kompiuteriuose. 